A

STUDIA Z PRAWA WYZNANIOWEGO

Tom $23-2020$

DOI: https://doi.org/10.31743/spw.9767

\author{
MICHAŁ SKWARZYŃSKI*
}

\title{
ANALIZA PRAWNA PRZYPADKU BPA EDWARDA JANIAKA W KONTEKŚCIE FILMU „ZABAWA W CHOWANEGO” MARKA I TOMASZA SEKIELSKICH
}

\section{Streszczenie}

Niniejsza analiza koncentruje się na kilku kluczowych zagadnieniach dotyczących przypadku ks. bpa Edwarda Janiaka, rozważanych w kontekście filmu Marka i Tomasza Sekielskich pt. „Zabawa w chowanego”. Punkt wyjścia stanowi określenie obowiązków hierarchy, zgodnie z obowiązującymi przepisami prawa polskiego i prawa kanonicznego, w związku z powzięciem przez niego informacji o przypadkach pedofilii podległych mu duchownych. Kolejne fragmenty analizy odnoszą się odpowiednio do rzetelności warstwy faktograficznej filmu, dokonanych w nim naruszeń obowiązujących przepisów i możliwości ochrony prawnej bpa Janiaka, a także pozaprawnych aspektów podjęcia przez niego aktywnej obrony. Przeprowadzone rozważania prowadzą do wniosku, że w omawianym filmie zafałszowano nie tylko chronologię zdarzeń, ale i rzeczywistość prawną. Natomiast wybór bpa Janiaka na negatywnego bohatera "Zabawy w chowanego" wynikał nie tyle z racji merytorycznych, ile raczej z faktu dysponowania nagraniami jego wypowiedzi, które można było w filmie wykorzystać.

Słowa kluczowe: zwalczanie pedofilii; Kościół Katolicki; dziennikarstwo; prawo kanoniczne

$* * * * *$

* Dr, Katedra Praw Człowieka i Prawa Humanitarnego, Wydział Prawa, Prawa Kanonicznego i Administracji, Katolicki Uniwersytet Lubelski Jana Pawła II, Al. Racławickie 14, 20-950 Lublin, e-mail: michal.skwarzynski@kul.pl. ORCID 0000-0002-4357-8035. 


\section{WPROWADZENIE}

Niniejsza analiza dotyczy czterech zagadnień, których omówienie jest konieczne do wyjaśnienia sytuacji prawnej i faktycznej ks. bpa Edwarda Janiaka jako negatywnego bohatera dużej część filmu Braci Sekielskich pt. „Zabawa w chowanego”. Rozważania dotyczą zarzutów stawianych bp. Janiakowi w tym filmie, jak również publicznie poza nim.

W pierwszej części opracowania precyzuje się obowiązki obciążające ks. bpa Edwarda Janiaka zgodnie z prawem polskim i prawem kanonicznym w sprawach, do których odnoszą się zarzuty stawiane w omawianym filmie. W kontekście problemu tzw. „wtórnej wiktymizacji ofiar” podejmuje się też kwestię personalnych i logistycznych możliwości szybkiego ustanowienia adekwatnych procedur badania tego rodzaju zdarzeń na poziomie diecezji oraz formułuje się wnioski dotyczące współpracy Kościoła i świeckiego wymiaru sprawiedliwości.

Kolejna część analizy dotyczy faktograficznej rzetelności Autorów filmu. Zawarty w nim przekaz jest tu konfrontowany z rzeczywistym stanem faktycznym w sprawie ks. K. i ks. H. Natomiast w dalszej kolejności uwaga skoncentrowana jest na możliwościach ochrony prawnej bpa Janiaka oraz dokonanych przez Autorów filmu naruszeniach obowiązujących przepisów, a także na pozaprawnych aspektach podjęcia aktywnej obrony hierarchy.

1. OBOWIĄZKI KS. BPA EDWARDA JANIAKA WYNIKAJĄCE Z PRAWA POLSKIEGO I PRAWA KANONICZNEGO W ZWIĄZKU Z ZARZUTAMI STAWIANYMI W FILMIE „ZABAWA W CHOWANEGO”, MOŻLIWOŚCI PERSONALNE I LOGISTYCZNE W KONTEKŚCIE PROBLEMU TZW. „WTÓRNEJ WIKTYMIZACJI OFIAR” PRZESTĘPCZOŚCI SEKSUALNEJ I KONIECZNOŚĆ WSPÓŁPRACY KOŚCIOŁA I ŚWIECKIEGO WYMIARU SPRAWIEDLIWOŚCI

Rozpoczynając analizę przedmiotowego zagadnienia wskazać należy na daty, w których weszły w życie przepisy określające poszczególne obowiązki, jakie nałożone zostały na adresatów norm w związku z podejrzeniem przypadku pedofilii duchownego Kościoła Katolickiego. Istotna jest również kwestia logistycznej i personalnej ochrony ofiar przestępstw 
seksualnych przed tzw. wtórną wiktymizacją. Oczywiście zagadnienie obowiązków publicznych i kanonicznych jest samoistnie na tyle rozbudowane i złożone, iż zasługiwałoby na oddzielne opracowanie. Podobnie jest z problemem tzw. wtórnej wiktymizacji ofiar przestępczości seksualnej. Odnosząca się do tego analiza ogranicza się zatem do tego, co jest konieczne dla dalszego wywodu.

\subsection{PRAWNOKARNY OBOWIĄZEK DENUNCJACJI PEDOFILII (ART. 240 K.K.)}

W prawie publicznym przepis dotyczący prawnego obowiązku zawiadomienia o podejrzeniu popełnienia przestępstwa pedofilii jest regulacją stosunkowo świeżą. Obowiązek taki wszedł w życie wraz ze zmianą art. 240 ustawy z dnia 6 czerwca 1997 r. - Kodeks karny (dalej: k.k.) $)^{1}$, z dniem 13 lipca 2017 r. $^{2}$ Otwarte pozostaje przy tym pytanie, czy i na ile przepis ten dotyczy osób objętych tajemnicą zawodową, co ma znaczenie zwłaszcza w przypadku duchownego czy obrońcy. Wydaje się oczywiste, że to samo zachowanie nakazane przez normę prawną - a więc obowiązek utrzymania w tajemnicy pewnych okoliczności - nie może w ramach jednego spójnego systemu prawnego być jednocześnie obwarowany w pewnych zakresach odpowiedzialnością karną. Kwestia ta budzi jednak wątpliwości w doktrynie. Pamiętać należy, iż zakazem dowodowym objęte są informacje posiadane przez obrońcę w związku z prowadzeniem sprawy oraz przez duchownego - ze spowiedzi (art. 178 ustawy z dnia 6 czerwca 1997 r. - Kodeks postępowania karnego; dalej: k.p.k.)³. Według części doktryny nawet te osoby są zobowiązane do denuncjacji przestępstw ujętych w art. 240 k.k. Wydaje się jednak, że istota tajemnicy spowiedzi, tak jak tajemnicy obrońcy, wyklucza konieczność denuncjacji. Taka tajemnica straciłaby swój rdzeń i przestałaby spełniać swoją funkcję. Powstaje pytanie, czy zwolnienie z obowiązku denuncjacji odnosi się do osoby, która o popełnieniu przestępstwa objętego tym obowiązkiem dowie się

$1 \quad$ Tekst jedn. Dz. U. z 2019 r., poz. 1950.

2 Ustawa z dnia 23 marca 2017 r. o zmianie ustawy - Kodeks karny, ustawy o postępowaniu w sprawach nieletnich oraz ustawy - Kodeks postępowania karnego, Dz. U. z 2017 r., poz. 773. Ustawa ta weszła w życie w dniu 13 lipca 2017 r.

3 Tekst. jedn. Dz. U. z 2020 r., poz. 30. 
w czasie wykonywania czynności urzędowych, zwłaszcza „kanonicznych” (co może dotyczyć w szczególności pracowników kurii czy biskupów). W doktrynie wyrażono pogląd, iż działanie w ramach kontratypu uprawnień i obowiązków zwalnia z odpowiedzialności ${ }^{4}$. Nie można oczywiście pominąć faktu, że osoba, która pracuje w kurii czy biskup dowiadują się o przestępstwie objętym art. 240 k.k. w ramach wykonywanych funkcji administracyjnych, a nie $\mathrm{w}$ ramach spowiedzi. Natomiast wykonywanie funkcji administracyjnej, nawet władczej (jak w przypadku biskupa), nie wiąże się z obowiązkiem zachowania uzyskanej w tym trybie wiedzy w tajemnicy. Jest wręcz odwrotnie. Kodeks Prawa Kanonicznego (dalej: KPK) ustanawia obowiązki dotyczące wszczęcia karnego procesu kanonicznego (zob. pkt 1.2. analizy). Daje to refleks w prawie publicznym. Osoby, o których tu mowa, co do informacji uzyskanych w ramach wykonywania swoich obowiązków - inaczej niż w przypadku wiadomości uzyskanych ze spowiedzi - są objęte obowiązkiem denuncjacji, co od 13 lipca 2017 r. dotyczy także przestępstwa pedofilii.

Istotne znaczenie posiada jednak fakt, że warunkiem koniecznym powstania omawianego obowiązku jest wiarygodność informacji o przestępstwie, o czym wyraźnie stanowi się w art. 240 § 1 k.k. Osoba zobligowana do denuncjacji nie popełnia ponadto przestępstwa określonego w tym przepisie, jeśli ma dostateczną podstawę do przypuszczenia, że właściwy organ wie o dokonanym czynie (art. $240 \S 2$ k.k.). Z punktu widzenia osoby, która pracuje w kurii czy biskupa o wiarygodności informacji można mówić z pewnością, gdy zakończy się proces kanoniczny stwierdzający winę. Jest jednak faktem, że bardzo często taka informacja jawi się jako wiarygodna już w czasie takiego procesu karnego kanonicznego, a nawet na samym jego początku (gdy np. sprawca się przyzna, czy są obiektywne, trudne do zakwestionowania dowody winy). Powstaje zatem problem, w jakim momencie i kto z kurii winien zawiadomić o toku lub wyniku postępowania kanonicznego. Jeśli zrobi to biskup lub sędzia w procesie kanonicznym, może to narażać sam proces kanoniczny na naruszenie jego

4 Zob. Zoll 2013, Komentarz do art. 240, uwagi 7-10; Bojarski 2016, Komentarz do art. 240, uwaga 4; Konarska-Wrzosek 2018, Komentarz do art. 240, uwaga 3; Stefański 2020, Komentarz do art. 240, uwaga 18; Banaś-Grabek, Gadecki, Karnat, Łyżwa, Łyżwa 2020, Komentarz do art. 240, uwaga 4; Gardocki 2020, Komentarz do art. 240, uwagi 63-64. 
dobra (które jest także dobrem publicznym). Sędzia w postępowaniu kanonicznym do chwili jego prawomocnego zakończenia winien zachować bezstronność. Podobnie powinien zachować się biskup. Wydaje się więc, że obowiązek denuncjacji należy odnieść do delegata, którego zadaniem jest ochrona dzieci i młodzieży właśnie przed przestępstwami seksualnymi ze strony duchownych. W interesie państwa i społeczeństwa pozostaje, żeby sprawca przestępstwa, do którego popełnienia wykorzystał funkcję duchownego, został tej funkcji pozbawiony. Jednak decyzja o usunięciu ze stanu duchownego może być podjęta jedynie przez właściwe władze związku wyznaniowego, do którego należy dany duchowny. Z oczywistych względów państwo nie może decydować o tym, kto jest duchownym. Ingerowałoby to w autonomię związków wyznaniowych i naruszało prawo człowieka do wolności religijnej ${ }^{5}$. Jednocześnie oczywistym jest, że osoba, która popełnia przestępstwo prawa państwowego, które jest również przestępstwem w prawie wewnętrznym związku wyznaniowego, powinna być poddana procedurze określonej w tym prawie wewnętrznym. Równie oczywistym i słusznie oczekiwanym społecznie jest, że sprawca powinien być zasadniczo pozbawiony funkcji, którą wykorzystał do popełnienia przestępstwa. Nie chodzi przy tym wyłącznie o pedofilię, choć w tym przypadku sprawa wydaje się najbardziej oczywista. Takie sytuacje powinny się spotkać z adekwatną reakcją władz związku wyznaniowego, aby funkcja duchownego nie była wykorzystywana do dokonywania przestępstw publicznych i kanonicznych. Państwo i społeczeństwo oczekują tutaj oczywistej reakcji i w tym zakresie państwo oraz związek wyznaniowy powinny współdziałać. Powinny też jednak zapewnić prawo do rzetelnego procesu osobie pozbawianej funkcji duchownego, a w związku z tym należy oczekiwać, że państwo będzie respektować tok postępowania obowiązującego w związku wyznaniowym. Wszak pozbawienie przestępcy funkcji duchownego pozostaje w interesie państwa i społeczeństwa.

Wracając do obowiązku denuncjacji pedofilii, jeśli sprawa jest oczywista - sprawca się przyzna, jest dowód materialny, np. wiarygodne nagranie

5 Orzecznictwo ETPCz pozwala wskazać na sferę chronionej swobody grup wyznaniowych w postaci ich autonomii, która $\mathrm{z}$ kolei zawiera w sobie komponent dotyczący ustalania własnej struktury organizacyjnej oraz decydowania o tym, kto jest duchownym. Szerzej: Garlicki 2010, uwagi 34, 40 i 42; Skwarzyński 2019, 223-238; Skwarzyński 2018, 71-88. 
(zwłaszcza wideo) ${ }^{6}$ - obowiązek ten powstaje natychmiast. Z uwagi na niezakończenie postępowania karnokanonicznego nie powinien on spoczywać na biskupie czy sędziach kościelnych. Prawo do rzetelnego procesu, jako prawo człowieka wynikające z prawa naturalnego, przysługuje także sprawcy w postępowaniu kanonicznym i obejmuje zwłaszcza prawo do bezstronnego i niezawisłego sądu? . Sędzia czy biskup, który zawiadamia organy państwowe, traci walor bezstronnego i ujawnia swoją ocenę sprawy. Pamiętać przy tym należy, że denuncjacja przez biskupa czy sędziego nie jest konieczna, bowiem w postępowaniu rolę tę może spełniać właściwy delegat ds. ochrony dzieci i młodzieży.

Omawiana sytuacja tylko z pozoru jest prosta. W praktyce może się zdarzyć wiele wyjątkowo skomplikowanych przypadków. Będą sprawy, w których dojdzie do zwykłego pomówienia. To jednak będzie mogło zostać rozstrzygnięte dopiero w postępowaniu dowodowym, więc dojście do prawdy pozostanie kwestią czasu ${ }^{8}$. Podobnie będą sprawy niejednoznaczne, w których wiarygodność nie jest pewna na tyle, aby powstał obowiązek denuncjacji. Jeszcze trudniejsza może się okazać sytuacja, gdy obecnie pełnoletni pokrzywdzony, powołując się na traumę, nie chce się zgodzić na osobiste spotkanie z przedstawicielem związku wyznaniowego (problem ten jest rozważany w części 1.4.).

Jak o tym już była mowa, obowiązek denuncjacji nie powstaje, jeśli osoba zobowiązana do jego realizacji ma dostateczną podstawę do przypuszczenia, że właściwy w tych sprawach organ wie już o dokonanym czynie (art. $240 \S 2$ k.k.). Jeśli więc z przekazanych informacji lub oko-

6 Przy dzisiejszym stanie techniki nagrania audio dość łatwo jest zmanipulować. Zresztą przy nagraniach wideo jest to także możliwe, choć zdecydowanie trudniejsze (tzw. deep fake). Jednocześnie obecne możliwości dowodowe, jako opinia fonoskopijna czy audiowizualna, pozwalają na szybką weryfikację prawdziwości nagrania. Jeśli okaże się ono prawdziwe, posiada przymiot wiarygodności, co będzie determinować obowiązek denuncjacji.

7 Jest to standard międzynarodowy, tożsamy dla wszystkich systemów ochrony praw człowieka. Zob. Orzeszyna, Skwarzyński, Tabaszewski 2020, 309-323; Skwarzyński 2014, 103-121.

8 Rzetelne badania psychologiczne rzekomej ofiary, weryfikacja okoliczności pobocznych, okoliczności faktycznych samego rzekomego przestępstwa, rzetelna ocena dowodów, pozwalają wychwycić oskarżenie kłamliwe, choć wymaga to czasu i często wieloinstancyjnego postępowania (znamienny jest casus George'a Pella). 
liczności wynika, że pokrzywdzony sam skierował lub skieruje sprawę na drogę (świeckiego) postępowania karnego, należy sądzić, że obowiązek denuncjacji nie istnieje. Wystarczające jest przy tym uzasadnione przypuszczenie, że tak jest. Ustawodawca posługuje się tutaj dość niezręcznym sformułowaniem, iż osoba musi mieć ,dostateczną podstawę do przypuszczenia". Chodzi jednak niewątpliwie o to, aby omawiane przypuszczenie było prawdopodobne, a nie pozostawało frazesem wykorzystywanym w celu uniknięcia odpowiedzialności. Przykładem może być zgłoszenie się do kurii profesjonalnego pełnomocnika pokrzywdzonego (adwokata, radcy prawnego). Podobnie będzie w sytuacji postępowania przed sądem cywilnym (czy to w fazie pozwu czy jeszcze zawezwania do próby ugodowej), bowiem rozsądnym jest założenie, że jeśli toczy się sprawa o odszkodowanie i zadośćuczynienie to sąd cywilny zawiadomił organy ścigania o przestępstwie będącym przedmiotem tego postępowania.

Szczególne znaczenie w rozważanej sprawie ma fakt, że przed 2017 r. w prawie publicznym istniał wyłącznie społeczny obowiązek zawiadomienia o podejrzeniu popełnienia przestępstwa (art. 304 k.p.k.). Nie był on więc obwarowany jakąkolwiek sankcją (lex imperfecta). Tym samym w systemie prawa publicznego do dnia 13 lipca 2017 r. brak było prawnego obowiązku zawiadomienia o podejrzeniu popełnienia przestępstwa pedofilii.

Zgodnie ze stanem faktycznym (część 2 niniejszej analizy) bp Edward Janiak dowiedział się o sprawie ks. H. w marcu 2016 r. od rodziców pokrzywdzonego. Z punktu widzenia ówczesnego prawa publicznego nie miał on prawnego obowiązku poinformowania prokuratury. Odnosząc się natomiast do sytuacji zaistniałej po zmianie prawa, a więc po 13 lipca 2017 r. należy przyjąć, że posiadanie wyłącznie informacji pochodzącej od rodziców pokrzywdzonego nie mogło być uznane za wystarczającą przesłankę zawiadomienia organów ścigania. Powstaje zatem pytanie, czy ten obowiązek nie powstał później. Sprawa jest prosta, jeśli wiadomość nie była wiarygodna. Jeśli natomiast była taką, obowiązek zawiadomienia nie powstał, jeśli pokrzywdzony bądź jego rodzice sami zawiadomili organy ścigania. Trzeba przy tym zauważyć, że sprawy dotyczące pedofilii duchownych były już wtedy przedmiotem publicznej dyskusji, więc osoba mająca wiedzę o takim czynie w łatwy sposób mogła się dowiedzieć, w jaki sposób zawiadomić odpowiednie organy. Do rozważe- 
nia pozostaje najbardziej problematyczny przypadek, w którym pełnoletni pokrzywdzony nie chce żadnego postępowania (zob. pkt 1.4.) albo trudno ustalić jego rzeczywistą wolę.

Podsumowując tę część rozważań należy stwierdzić, ks. bp Edward Janiak nie naruszył obowiązków wynikających z prawa powszechnego zarówno w sprawie dotyczącej ks. H., jak i sprawie ks. K. (w tym ostatnim przypadku jest niewątpliwe, że w 2017 r. organy ścigania wiedziały o jego przestępstwach).

\subsection{OBOWIĄZKI WYNIKAJĄCE Z PRAWA KANONICZNEGO}

Kolejną kwestią są obowiązki wynikające z prawa wewnętrznego związku wyznaniowego, a więc w tym przypadku z Kodeksu Prawa Kanonicznego i przepisów niższej rangi. Istotny jest przy tym zwłaszcza kan. 1717. Zgodnie z jego $§ 1$, „Ilekroć ordynariusz otrzyma przynajmniej prawdopodobną wiadomość o przestępstwie, powinien sam lub przez inną odpowiednią osobę ostrożnie zbadać fakty i okoliczności oraz poczytalność, chyba że takie dochodzenie wydaje się zupełnie zbędne".

Niestety w przestrzeni publicznej funkcjonuje nieprawdziwe przekonanie, że List Apostolski motu proprio Sacramentorum sanctitatis tutela Jana Pawła II z dnia 30 kwietnia 2001 r. ${ }^{9}$ wraz z dokumentem Kongregacji Nauki Wiary Normae de gravioribus delictis w sposób kategoryczny zobowiązywał do dokonania stosownego zawiadomienia tej Kongregacji i zastrzegał jej bezwzględną właściwość w sprawach pedofilii. Po pierwsze, podstawowym celem tych dokumentów była ochrona Eucharystii i Sakramentu Pokuty. Po drugie, po stronie biskupa obowiązek nadal powstawał tylko wówczas, gdy otrzymana przez niego wiadomość była prawdopodobna, przy czym następnie miał też obowiązek ostrożnego zbadania faktów i przeprowadzenia postępowania wyjaśniającego. Dopiero $\mathrm{w}$ razie potwierdzenia podejrzeń powstawał obowiązek powiadomienia Kongregacji. Inaczej ujmując, nie było obowiązku powiadomienia Stolicy Apostolskiej o samym powzięciu niezweryfikowanej informacji czy o przyjętym w tej sprawie sposobie postępowania. Obowiązek powiado-

9 AAS 93 (2001), s. 737-739. 
mienia Kongregacji nie był bezwzględny, a wymagał przeprowadzenia postępowania wstępnego ${ }^{10}$. Znowu pojawia się więc problem dotyczący sytuacji, w której osoba pokrzywdzona nie zgłasza się osobiście lub nie chce ścigania (zob. część 1.5. niniejszej analizy). Do zmiany sytuacji słusznie doszło po publikacji Listu Apostolskiego motu proprio Vos estis lux mundi Papieża Franciszka z dnia 9 maja 2019 r., który zaczął obowiązywać z dniem 1 czerwca 2019 r. (zob. art. 19) ${ }^{11}$.

Art. $2 \S 3$ Listu Apostolskiego z dnia 9 maja 2019 r. posiada następujące brzmienie: „Z zachowaniem postanowienia artykułu $3 \S 3$, ordynariusz, który otrzymał zawiadomienie, przekaże je niezwłocznie ordynariuszowi miejsca, gdzie zaistniały zdarzenia, jak również ordynariuszowi własnemu, osoby, której dotyczy zgłoszenie, którzy postępują zgodnie z prawem, według tego, co przewidziano w danym przypadku" ${ }^{\prime 2}$. Obowiązek powiadomienia Stolicy Apostolskiej już o samym powzięciu informacji o możliwym przestępstwie wynika wprost z art. 10 („Obowiązki wstępne metropolity”) omawianego Listu Apostolskiego. § 1 tego artykułu brzmi: „Poza przypadkiem, kiedy zawiadomienie jest ewidentnie bezpodstawne, metropolita bezzwłocznie prosi kompetentną dykasterię o powierzenie mu zadania rozpoczęcia dochodzenia. Ilekroć metropolita uzna zawiadomienie za zdecydowanie bezpodstawne, informuje o tym przedstawiciela papieskiego". Tym samym o sprawie zawsze musi wiedzieć Stolica Apostolska lub przedstawiciel papieski. Z kolei kompetentną dykasterię określa art. 7 Listu Apostolskiego z dnia 9 maja 2019 r. ${ }^{13}$ Oczywiście wprost

10 Zob. Dohnalik 2015, 50-66; Mazurkiewicz 2018, 45-68; Domaszk 2012, 69-86.

11 „Osservatore Romano” z 9 maja 2019 r.; dalej: List Apostolski z dnia 9 maja 2019 r.

12 Art. $3 \S 3$ : „Gdy zawiadomienie dotyczy jednej z osób wskazanych w art. 6, jest ono skierowane do władzy określonej na podstawie art. 8 i 9. Zawiadomienie może być zawsze skierowane do Stolicy Apostolskiej bezpośrednio lub za pośrednictwem przedstawiciela papieskiego".

13 Art. 7 („Dykasteria kompetentna”):

„§ 1. W rozumieniu tytułu, «dykasteria kompetentna» oznacza Kongregację Nauki Wiary, w odniesieniu do przestępstw zastrzeżonych dla niej przez obowiązujące prawo, a także we wszystkich innych przypadkach i w zakresie, w jakim dotyczy to ich właściwej jurysdykcji, zgodnie z prawem własnym Kurii Rzymskiej:

Kongregację dla Kościołów Wschodnich;

Kongregację ds. Biskupów;

Kongregację ds. Ewangelizacji Narodów; 
formalnie odnosi się to do sytuacji, gdy ordynariusz nie podjął działań, ale w praktyce stosowania, wszelkie sytuacje i same wiarygodne wiadomości/ zawiadomienia dotyczące domniemanych przestępstw duchownych wobec małoletnich są zgłaszane Stolicy Apostolskiej. Tym samym, treść Listu Apostolskiego z dnia 9 maja 2019 r. zmieniła praktykę stosowania prawa kanonicznego. Oznacza to, że obowiązek informowania o samym zawiadomieniu zaczął obowiązywać od dnia 1 czerwca 2019 r. Istotny jest przy tym art. 19 (zdanie 1) Listu Apostolskiego z dnia 9 maja 2019 r., zgodnie z którym „niniejsze przepisy stosuje się bez uszczerbku dla praw i obowiązków ustanowionych gdziekolwiek w ustawodawstwie państwowym, w szczególności dotyczących ewentualnych obowiązków zawiadomienia właściwych władz cywilnych". Wcześniej konieczne było przeprowadzenie wstępnego postępowania wyjaśniającego.

Ks. bp Edward Janiak o sprawie ks. H dowiedział się w marcu 2016 r. od rodziców pokrzywdzonego (zob. część 2 niniejszej analizy). Po zmianie prawa, więc po 1 czerwca 2019 r., toczyło się już postępowanie karne kanoniczne i państwowe wobec ks. H. Można więc stwierdzić, że bp Edward Janiak nie naruszył żadnych swoich obowiązków wynikających z prawa kanonicznego zarówno w odniesieniu do spraw ks. H. i ks. K. ${ }^{14}$

\subsection{MOŻLIWOŚCI PERSONALNE I LOGISTYCZNE}

W tym miejscu materializuje się podstawowy problem każdego postępowania w sprawach wrażliwych, jakim jest konieczność stworzenia procedury i organu badającego dane zdarzenie. Zdecydowanie łatwiej wdrożyć wszelkie rozwiązania komuś kto ma wiedzę specjalną, jest wykwalifikowanym prawnikiem, psychologiem, pedagogiem itd. Biskupi jednak zasadniczo mają wykształcenie teologicznie, rzadziej prawno-kanoniczne, co zresztą nie może dziwić. Wykształceniem teologicznym legi-

\footnotetext{
Kongregację ds. Duchowieństwa;

Kongregację ds. Instytutów Życia Konsekrowanego i Stowarzyszeń Życia Apostolskiego. $\S 2$. Dykasteria postępuje bezzwłocznie, a w każdym razie w ciągu trzydziestu dni od otrzymania pierwszego zawiadomienia ze strony przedstawiciela papieskiego lub wniosku o powierzenie zadania przez metropolitę, dostarczając stosowne instrukcje dotyczące trybu postępowania w konkretnym przypadku".

14 Postępowanie kanoniczne dotyczące ks. K. w 2019 r. było już zakończone.
} 
tymuje się również ks. bp Edward Janiak. Biskupi zatem muszą polegać na wiedzy prawniczej pracowników kurii, która - niestety - nie zawsze jest na odpowiednim poziomie. Konsekwencje takiego stanu rzeczy spadają następnie na biskupa, episkopat i cały Kościół.

Zwykłym populizmem jest wymaganie, aby właściwy organ, czy to państwowy, czy kościelny, w sprawach dotyczących pedofilii od razu precyzyjnie wiedział, jaki był stan faktyczny, a w związku z tym był od razu gotowy do wydania rozstrzygnięcia. Tego typu sprawy wymagają jednak starannej regulacji, aby z jednej strony zapewnić ochronę rzeczywistym pokrzywdzonym tego typu przestępczością, a $\mathrm{z}$ drugiej zagwarantować prawo do obrony osobom oskarżanym o popełnienie przestępstwa i nie dopuścić do skazania osoby niewinnej. Zrównoważenie tych dóbr nie jest ani łatwe, ani oczywiste. Odnoszą się do tego obszerne regulacje postępowania sądowego. Problem ten niełatwo jest jednak rozwiązać w sposób proceduralny ${ }^{15}$. Praktyka stosowania prawa jest niestety zdehumanizowana, co w tego rodzaju sprawach jest szczególnie bolesne dla ofiar. Pewną podpowiedź dla działań organów kościelnych może stanowić regulacja ochrony pokrzywdzonego, jaką przyjęto na gruncie polskiej procedury karnej. Podstawową kwestią powinno być szkolenie osób, które mają kontakt z osobami pokrzywdzonymi. Powinny to być osoby, które wiedzą, jak nie pogłębiać traumy, a wiedza taka może być przekazana przez wykształconego w tym kierunku psychologa. Trzeba mieć także szczególne predyspozycje osobowościowe. W art. 185a, 185b, 185c k.p.k. zakłada się przesłuchanie w obecności psychologa, bez obecności sprawcy. Zasadniczo przesłuchanie nie powinno być powtarzane. Jest ono nagrywane, w pomieszczeniu przystosowanym przyjaźnie dla dziecka (pokój wygląda jak pokój dziecięcy), gdzie z dzieckiem przebywają psycholog i sędzia. Obrońca, prokurator, rodzice i protokolant zasadniczo przebywają za „lustrem weneckim”. Zasadą jest, że pytania są formułowane przez psychologa i sędziego. Pytania stron są przekazywane sędziemu i on je zadaje pokrzywdzonemu. Nie pozwala to oczywiście na całkowite uniknięcie przez pokrzywdzonego traumy samego przesłuchania. Starania zmierzające do jej zminimalizowania są jednak wyraźne.

15 Zob. wyrok ETPCz z dnia 19 czerwca 2007 r. w sprawie W.S. p-ko Polsce, skarga nr 21508/02, § 53-64; Balcerzak 2008, 175-182. 


\subsection{PROBLEM TZW. „WTÓRNEJ WIKTYMIZACJI OFIAR” PRZESTĘPCZOŚCI SEKSUALNEJ}

Zjawisko tzw. „wtórnej wiktymizacji ofiar” polega na dalszym doznawaniu przez nie negatywnych doświadczeń, związanych w tym przypadku $\mathrm{z}$ traumą seksualną (pedofilia, molestowanie itd.). Źródłem tych doświadczeń jest: konieczność opowiedzenia o traumatycznym zdarzeniu, konieczność zeznawania $\mathrm{w}$ formule procesowej (zarówno w postępowaniu przed organami państwowymi, jak i kościelnymi), obawa przed wydostaniem się informacji do rodziny i społeczności lub niewłaściwe traktowanie przez otoczenie społeczne i oficjalne instytucje, jeżeli taka informacja się wydostanie ${ }^{16}$.

Problem wtórnej wiktymizacji jest najczęściej podnoszony przy przestępstwie zgwałcenia. W 2014 r. polski ustawodawca zdecydował się na zmianę dotychczasowego przepisu, iż ściganie następuje na wniosek pokrzywdzonego, na tryb ścigania z urzędu. Generalnie celem nowelizacji była chęć pomocy pokrzywdzonym, którzy z obawy przed sprawcą nie zgłaszali tego typu przestępstw. Jako wątpliwość do tej zmiany podnoszono właśnie wtórną wiktymizację ofiar zgwałcenia, które mogą nie chcieć odświeżać i ponownie doświadczać przeżytej traumy. Ustawodawca uznał chyba zasadnie, że pojedyncze sytuacje tego typu nie uzasadniają generalnego odstąpienia od ścigania w przypadku pokrzywdzonych bez pomocy, którzy z różnych powodów nie złożą wniosku o ściganie. W przypadku pedofilii szereg kwestii przedstawia się podobnie. Jeśli mamy do czynienia z dzieckiem, nie jest ono oczywiście w stanie zrozumieć konsekwencji przestępstwa jakiego było ofiarą. Dziecko jest w tym zakresie chronione przez rodziców/opiekunów prawnych oraz organy ścigania i wymiaru sprawiedliwości z urzędu. Ale w praktyce ofiary pedofilii zgłaszają się często już jako osoby dorosłe. Mamy zatem sytuację analogiczną, jak przy zgwałceniu. Jednak dorosła osoba może nie chcieć ani zawiadamiania organów państwowych, ani procesu kanonicznego i domagać się - na przykład wyłącznie odsunięcia sprawcy od pracy z dziećmi. Jako wyjątkowo trudna jawi się sytuacja, w której obecnie pełnoletni pokrzywdzony, wskutek prze-

16 Szerzej: Mazowiecka 2012, passim; Wójcik 2014 (Część III: Wiktymizacja kryminalna a skutki przestępczości); Kierski 2018, 87-88; postanowienie SN z dnia 30 września 2010 r., sygn. akt I KZP 21/10; wyrok SN z dnia 20 stycznia 2016 r., sygn. akt III KK 187/15. 
żytej traumy, nie chce osobiście ani dokonać zgłoszenia, ani składać jakichkolwiek zeznań i trudno ustalić, jaka jest jego rzeczywista wola. Sytuacje te wymagają rozwiązania zarówno na poziomie prawa państwowego, jak i prawa kanonicznego. Bezwzględnie prymatem w takich sytuacjach musi być przy tym dobro pokrzywdzonego. Nie wolno takiej osoby do niczego zmuszać, co jednak oczywiście nie może oznaczać bezkarności sprawcy. Zarówno w prawie państwowym, jak i w prawie kanonicznym, konieczne jest szybkie zapewnienie pokrzywdzonemu adekwatnej terapii psychologicznej, aby po jej przejściu mógł złożyć zeznania z jak najmniejszą traumą (nie zwalnia to oczywiście ani instytucji kościelnych, ani państwowych od zbierania pozostałego materiału dowodowego). Bez wątpienia, na tego rodzaju sytuacje należy potrzeć z uwzględnieniem punktu widzenia pokrzywdzonego. O jego wykorzystaniu seksualnym w przeszłości może przecież nie wiedzieć rodzina (rodzice, rodzeństwo, małżonek) i ujawnienie tej okoliczności może być dla niego wyjątkowo trudne. W przypadku dorosłego pokrzywdzonego nie ma konieczności szybkiego przesłuchania, które istnieje w przypadku dziecka z uwagi na możliwość zapomnienia czy konieczność bezzwłocznego leczenia psychologicznego. W przypadku dorosłej osoby będącej ofiarą pedofilii pośpiech nie jest konieczny, a przy podejmowaniu decyzji o przesłuchaniu powinien być uwzględniany stan tej osoby. Konieczne jest szybkie zapewnienie terapii psychologicznej takiej ofierze, aby po jej przejściu mogła spokojnie złożyć zeznania, z jak najmniejszą traumą. Aby uniknąć podwójnego przesłuchiwania pokrzywdzonego, raz w procesie państwowym a raz w kanonicznym, rozważyć należy, czy nie zawrzeć porozumienia z państwem, aby w takich sprawach, gdzie nie doszło do przedawnienia przestępstwa państwowego, to organy państwowe przeprowadzały śledztwo i przekazywały materiał dokumentacyjny po jego zakończeniu na potrzeby sprawy do sądu biskupiego. Nie będzie wtedy konieczności przesłuchiwania świadków, a zwłaszcza ofiary. Jest to szczególnie ważne w sytuacji przesłuchiwania dziecka w trybie art. 185a i następnych k.p.k. Dziecko takie będzie przesłuchiwane w optymalnych warunkach - w niebieskim pokoju, w obecności psychologa i sędziego. $\mathrm{Z}$ tej czynności będzie nagranie, ale także dokładny protokół, natomiast w aktach będą opinie biegłych psychologów na temat dziecka. Te dokumenty będą wystarczające do przeprowadzenia postępowania kanonicznego. Zminimalizuje się w ten sposób wtórną wiktymizację pokrzywdzonego. 


\subsection{KONIECZNOŚĆ WSPÓŁPRACY KOŚCIOŁA I ŚWIECKIEGO WYMIARU SPRAWIEDLIWOŚCI}

Postulat współpracy instytucji państwowych i kościelnych w sprawach związanych ze ściganiem przestępstw popełnianych przez duchownych zwłaszcza na szkodę małoletnich jawi się jako oczywistość. Zarówno związek wyznaniowy, jak i organy państwa są (a w każdym razie powinny być) w sposób naturalny zainteresowane wyjaśnieniem stanu faktycznego. W ich interesie, a nadto w interesie społecznym jest, aby osoba winna poniosła odpowiedzialność, a osoba niewinna jej nie poniosła, a także, aby orzeczona kara była adekwatna do czynu, a sprawca nie miał już więcej sposobności do popełnienia tego typu przestępstw. Zarówno związek wyznaniowy, jak i organy ścigania, powinny współpracować zwłaszcza w zakresie dowodowym. Z oczywistych względów państwo jest lepiej przygotowane do zbierania materiału dowodowego i ustalania faktów. Musi też ono jednak umożliwić uczciwe przeprowadzenie przez związek wyznaniowy procedur związanych z pozbawieniem funkcji duchownego.

\section{RZETELNOŚĆ FAKTOGRAFICZNA A NARRACJA} PRZEDSTAWIONA W FILMIE „ZABAWA W CHOWANEGO”

Dążąc do odpowiedzi na pytanie dotyczące rzetelności przekazu zawartego w filmie „Zabawa w chowanego" należy najpierw przedstawić rzeczywisty stan faktyczny sprawy ks. K. i ks. H., uwzględniając w szczególności okresy sprawowania przez nich poszczególnych urzędów, a następnie zestawić to z przekazem filmowym.

\subsection{RZECZYWISTY STAN FAKTYCZNY SPRAW KS. K. I KS. H.}

Ks. K. był bohaterem pierwszego filmu Braci Sekielskich „Tylko nie mów nikomu". Biskup E. Janiak był wtedy biskupem pomocniczym we Wrocławiu. Kwestię przenosin między Wrocławiem a Bydgoszczą rozstrzygali między sobą ordynariusze tych diecezji. Biskup pomocniczy w tej sprawie był wyłącznie wykonawcą poleceń, co jest oczywiste, jeśli uwzględni się strukturę hierarchiczną Kościoła. 
Sam bp Janiak, na włączonym do filmu nagraniu z rozprawy mówi, że nie wiedział o poręczeniach majątkowych dla ks. K. ze strony arcybiskupów wrocławskich ${ }^{17}$. Można więc sądzić, że przełożony nie przekazywał mu całości informacji. Trudno przypisywać odpowiedzialność biskupowi pomocniczemu, który nie mając pełnego obrazu wykonuje polecenie arcybiskupa. Z kolei odpowiedź bpa Janiaka na pytanie o jego ówczesną wiedzę o pedofilii i prowadzonym przeciwko ks. K. postępowaniu karnym („nie mówię nie i nie mówię tak”) jest ewidentnie ucięta ${ }^{18}$. Nietrudno jest się przy tym domyślić, że chodzi o odróżnienie wiedzy posiadanej z oficjalnych źródeł od plotek i domysłów.

W 2005 r. ks. K. został - co prawda - zatrzymany w związku z dalej idącymi zarzutami, ale prawomocnie został skazany jedynie za posiadanie pornografii dziecięcej ${ }^{19}$. Sytuacji nie można oceniać z perspektywy okoliczności (zwłaszcza czynów ks. K.), które ujawniły się dopiero w 2012 r. Postępowanie kanoniczne toczyło się od 2005 r. i opierało się na dowodach zgromadzonych w postępowaniu świeckim. Ostatecznie ks. K. został odsunięty od pracy z dziećmi. Trudno sądzić, że sąd biskupi miał lepsze narzędzia dowodowe niż prokuratura. Nie można też zakładać posiadania wiedzy o nieznanych faktach przez biskupa.

W kwestii przenosin ks. K. w 2005 r. bp Janiak (wówczas biskup pomocniczy) działał w oczywisty sposób w zaufaniu do przełożonego i ordynariusza w Bydgoszczy. Brak jest jakiegokolwiek dowodu, że miał pełną wiedzę na temat zachowań ks. K. Jasne jest ponadto, że bp Janiak nie odpowiada za to, gdzie ks. K. został skierowany przez biskupa w Bydgoszczy. Z kolei po odesłaniu ks. K. z Bydgoszczy z powrotem do Wrocławia o jego losie decydował arcybiskup, a nie biskup pomocniczy. Materiały prasowe i filmy tej kwestii w żadnym miejscu nie wyjaśniają i nie dokumentują faktograficznie zarzutów, a całe sprawstwo i wiedzę przypisują bp. Janiakowi. Mało tego, prawnik Janusz Mazur sam wskazuje, że sprawa

17 49:44-50:40 filmu „Zabawa w chowanego”.

18 48:39-49:17 filmu „Zabawa w chowanego”. Nie dziwi zatem wniosek, aby opublikować całość zeznań biskupa z sądu, zob. https://wpolityce.pl/kosciol/503386-czy-trzeba-poswiecic-prawde-w-walce-z-pedofilia [dostęp: 1.06.2020].

19 Daniel Flis, Czterej biskupi i jeden kardynat kryli księdza-pedofila. Są: Kurie maja zapłacić 300 tys. zł ofierze, https://oko.press/czterech-biskupow-i-jeden-kardynal-kryli-ksiedza-pedofila-sad-kurie-maja-zaplacic-300-tys-zl-ofierze [dostęp: 1.06.2020]. 
ks. K. „wybuchła” w 2012 lub 2013 r., kiedy bp Janiak był biskupem w Kaliszu ${ }^{20}$. Według narracji filmu i mediów ks. bp Edward Janiak odpowiada za decyzje w sprawie ks. K., chociaż to nie on je podejmował. Odpowiedzialność ta - jak to wynika z filmu - ma obejmować nawet okres przebywania ks. K. w innej diecezji oraz czas, w którym bp Janiak nie był już biskupem pomocniczym we Wrocławiu. Podobna „metodologia” jest przyjęta zresztą również w odniesieniu do ks. H. W tym przypadku bp Janiak ma odpowiadać za jego wielokrotne przenosiny w okresie, gdy nie był jeszcze biskupem kaliskim. Taką samą narrację przyjęto zresztą w wielu materiałach prasowych, w których zupełnie nie zważa się na istotne daty ${ }^{21}$.

Sprzeczności wynikające $\mathrm{z}$ podawanych dat dostrzec można nawet w jednym z artykułów opublikowanych w postrzeganym jako „życzliwy” Kościołowi portalu OKO.press. Z jednej strony stwierdza się tam, że ks. H. „od kiedy w 1994 roku przyjmuje święcenia kapłańskie, jest przenoszony podejrzanie często. Posługuje w: Koźminie Wielkopolskim, Sycowie, Pleszewie, Kaliszu, Lubini Małej, Mirkowie, Chwaliszewie (2012-2016), Skalmierzycach, a od lipca 2017 roku zostaje kapelanem Wojewódzkiego Szpitala Zespolonego im. Ludwika Perzyny w Kaliszu. Historie przedstawione w filmie Sekielskich dotyczą więc jednych z pierwszych parafii $\mathrm{H}$ (...), w których pracował ok. 20 lat temu”. Wcześniej jednak w tym samym tekście wskazuje się, że za sytuację z ks. H. „odpowiedzialny był m.in. biskup Edward Janiak, wcześniej biskup pomocniczy archidiecezji wrocławskiej, a od 2012 roku ordynariusz diecezji kaliskiej”22.

20 51:05-51:18 filmu ,Zabawa w chowanego”.

21 Zob. np. Sebastian Klauziński, Bp Janiak tuszowat pedofilię w Kościele trzy razy. OKO.press uzupetnia nowy film Sekielskich, https://oko.press/biskup-edward-janiak-sekielscy-zabawa-w-chowanego/ [dostęp: 1.06.2020]. Kwestie te analizuje A.G. w publikacji pt. Czy trzeba poświęcić prawdę $w$ walce z pedofilia?? „Nie można biskupowi Janiakowi zarzucać «zabawy w chowanego»", https://wpolityce.pl/kosciol/503386-czy-trzeba-poswiecic-prawde-w-walce-z-pedofilia [dostęp: 1.06.2020].

22 Sebastian Klauziński, Bp Janiak tuszowat pedofilię w Kościele trzy razy. OKO.press uzupetnia nowy film Sekielskich, https://oko.press/biskup-edward-janiak-sekielscy-zabawa-w-chowanego/ [dostęp: 1.06.2020]. W kolejnej publikacji (Kuria otaczała troska ks. Edwarda P. skazanego za molestowanie. Przez 19 lat, https://oko.press/kuria-wroclawska-ksiadz-edward-molestowanie-rekolekcje/; dostęp: 1.06.2020) S. Klauziński zarzuca bp. Janiakowi, że kłamał w sprawie ks. Edwarda P. i tuszował ją. Przytoczona jest tu wypowiedź bpa Janiaka dla „Gazety Świdnickiej” z 25 lutego 2003 r., który stwierdza, że miejsce Edwarda P. 
Trudno zrozumieć, na jakiej zasadzie biskup, który obejmuje diecezję kaliską dnia 12 września 2012 r., ma odpowiadać za zrealizowane przed tą datą przenosiny ks. H. Również skierowanie go na probostwo w Chwaliszewie nie jest decyzją bpa Janiaka, bowiem ks. H. objął je z dniem 1 lipca 2012 r. (1 lipca to zresztą w tej diecezji typowa data przenosin).

Z filmu wynika, że na początku marca 2016 roku do ks. bpa Edwarda Janiaka zgłosili się rodzice jednego z pokrzywdzonych przez ks. $\mathrm{H} \cdot{ }^{23} \mathrm{Na}$ nagraniu można dostrzec wzburzenie biskupa Janiaka sugestią, że wiedział o skłonnościach ks. H. Fakt, że hierarcha nie posiadał na ten temat wiedzy wydaje się oczywisty, jeśli weźmie się pod uwagę następujące potem fakty. Co więcej, biskup poprosił o zgłoszenie się pokrzywdzonego osobiście. Nie mógł przecież wiedzieć, jaka jest decyzja pokrzywdzonego, w jakiej formie jest gotów nawiązać kontakt, czy potrzebuje pomocy. Nie wiedział też, czy pokrzywdzony jest gotowy na przesłuchanie oraz czy o sytuacji wie małżonek. Nie można było wykluczyć, że wiedzę o całej sytuacji posiadają rodzice pokrzywdzonego, ale nie ma jej żona. Jak w takiej sytuacji można było choćby dyskretnie wezwać pokrzywdzonego? Przecież nie da się tego zrobić kierując oficjalny list z sądu biskupiego. Jak można było ustalić dogodny dla pokrzywdzonego termin, w którym będzie w stanie złożyć zeznanie z jak najmniejszą szkodą dla siebie? Są to prozaiczne kwestie, których nie sposób wyjaśnić z rodzicami. Niestety w Kościele brakuje $\mathrm{w}$ tych sprawach wiążących procedur. Nie inaczej jest jednak w prawie państwowym: wezwanie z prokuratury jest zawsze źródłem plotek i wtórnej wiktymizacji.

W dniu 9 marca 2016 r. nastąpiła degradacja ks. H. i zwolnienie go z urzędu proboszcza. Powody tej decyzji biskup ujawnił trzem przedstawicielom delegacji z parafii, w której ks. H. posługiwał. Opisała to w dniu 22 marca 2016 r. „Gazeta Krotoszyńska” oraz portale OKO.press

jest w domu księży emerytów lub domu opieki nad chorymi i już nigdy nie będzie on pełnić posługi kapłańskiej. Później wskazuje się, że ks. Edward P. został proboszczem. Jednak brakuje dowodu, że to bp Janiak (wówczas biskup pomocniczy) podjął tę decyzję (która należała do arcybiskupa). Dalej zarzuca się, że ks. Edward P. prowadził rekolekcje dla dzieci w 2019 r. To jednak nie ma żadnego związku z bp. Janiakiem.

23 39:52-41:39 filmu ,Zabawa w chowanego”. 
i wpolityce $^{24}$. Można zatem zadać pytanie, czego bp Janiak zaniedbał. Zareagował w ciągu kilku dni. Oczywistym jest natomiast, że jeśli poprzednik lub kurialiści nie poinformowali nowego biskupa o przyczynach 7-krotnych przenosin ks. H., to dowiedział się on o tym w marcu 2016 r. Nie może więc dziwić zdenerwowanie bpa Janiaka na sugestię, iż wiedział o problemach ks. H. wcześniej. W 2017 r. ks. H. został kapelanem szpitala w Kaliszu, co z pewnością nie jest awansem. Stanowi raczej decyzję mocno utrudniającą kontakt ks. H. z nieletnimi. Trzeba przy tym raz jeszcze podkreślić, że w tym czasie bp Janiak dysponował wyłącznie zgłoszeniem rodziców. Zapewne też dowiedział się, że ks. H. w rozmowie z rodzicami poszkodowanego przyznał się i że zostało to nagrane. Zgodnie z obowiązującym wówczas prawem kanonicznym, przed przeprowadzeniem postępowania wstępnego hierarcha nie zgłaszał sytuacji Stolicy Apostolskiej. Przeprowadzenie tego postępowania było jednak utrudnione przez brak kontaktu z pokrzywdzonym. W takiej sytuacji trudno o rozwiązania proste i oczywiste. Z pewnością natomiast niewłaściwe byłoby przeprowadzenie postępowania bez pokrzywdzonego. Ma on wszak prawo do ochrony ze strony prawa kanonicznego. Jednocześnie nie można zapominać, że również w procesie kanonicznym wobec ks. H. obowiązywało wówczas domniemanie niewinności. Decyzja podjęta przez bpa Janiaka nie wydaje się w tym świetle nieracjonalna.

Z filmu wynika, że 10 listopada 2018 r. pokrzywdzeni innymi czynami ks. H. spotkali się z prawnikiem. Zapewne w celu przerwania biegu przedawnienia, jeszcze w 2018 r. sprawa została skierowana do prokuratury i do sądu cywilnego. Z informacji z filmu i mediów wynika, że kuria udostępniła prokuraturze akta, zawiadomiła kongregację i uzyskała dokumenty z prokuratury. W konsekwencji doszło do suspensy i zakazu wykonywania przez ks. H. wszystkich czynności wynikających z władzy święceń oraz noszenia stroju duchownego. Prokuratura postawiła ks. H. zarzuty o popełnienie czynów z art. $200 \S 1$ k.k. w zw. z art. $12 \S 1$ k.k.

Przeprowadzona analiza prowadzi do wniosku, że w omawianej sprawie ks. bp Edward Janiak dopełnił obowiązków, jakie spoczywały na nim

24 Zob. Sebastian Klauziński, Bp Janiak tuszowat pedofilię w Kościele trzy razy. OKO. press uzupetnia nowy film Sekielskich, https://oko.press/biskup-edward-janiak-sekielscy-zabawa-w-chowanego/ [dostęp: 1.06.2020] oraz analiza autorstwa A.G. (https://wpolityce. pl/kosciol/503386-czy-trzeba-poswiecic-prawde-w-walce-z-pedofilia; dostęp: 1.06.2020). 
zgodnie z prawem polskim i prawem kanonicznym. Oczywiście można zarzucać, że chciał zgłoszenia pełnoletniego pokrzywdzonego. Trudno było jednak w inny sposób ustalić, czego on oczekuje. Jak wskazano wyżej, tego typu sytuacje bynajmniej nie są proste.

\subsection{PRZEKAZ FILMU „ZABAWA W CHOWANEGO”}

Autor niniejszej analizy zdaje sobie sprawę, że dążenie do prawdy którym się kieruje - może być przedstawiane jako obrona przestępców. Prawda o tym filmie nie może być jednak przemilczana. Tymczasem milczą o tym organy, które powinny tę kwestię podjąć z urzędu, jak choćby Rzecznik Praw Obywatelskich, Prokuratura, Urząd Ochrony Danych Osobowych czy Samorząd Dziennikarski. Upływ czasu bez wątpienia pozwoli na weryfikację tez stawianych w niniejszym tekście, który zresztą może być też odczytywany jako tekst o kondycji środowiska dziennikarskiego.

Oczywiście samo zajmowanie się zjawiskiem pedofilii przez media jest w pełni uzasadnione. Dotyczy to również kręcenia na ten temat filmów. Jest przy tym oczywiste, że istnieją układy lokalne chroniące pedofilię. Dowodzą tego chociażby filmy S. Latkowkiego: „Nic się nie stało” oraz „Pedofile”. Jest niestety również jasne, że strategia „zamiatania pod dywan" stosowana była m.in. przez niektórych hierarchów kościelnych oraz że koledzy duchownych - pedofilów niejednokrotnie pokrywali sprawę milczeniem. Takie zjawiska muszą być piętnowane także przez przekaz filmowy. Powstaje jednak pytanie o źródło dziennikarskiej siły. Jest nim bez wątpienia godność i prawa człowieka. Dziennikarz pozwala realizować prawo człowieka do uzyskania rzetelnej informacji i tylko wtedy wypełnia swoje zadanie, gdy jego przekaz jest oparty na prawdzie. Autor tej analizy, mając świadomość oddziaływania prawdy, dąży do przedstawienia tego, co jest zwykle przemilczane w odniesieniu do filmu „Zabawa w chowanego".

Film przedstawia bpa Janiaka jako głównego negatywnego bohatera ze strony biskupów. Odpowiednia narracja była zresztą przygotowywana jeszcze przed publiczną emisją „Zabawy w chowanego" 25 .

25 Zob. Sebastian Klauziński, Biskup kryje księdza, państwo kryje biskupa. Widzieliśmy nowy film braci Sekielskich, https://oko.press/zabawa-w-chowanego-sekielski-film 
Oczywiście sam film opisuje ks. H. i historię pokrzywdzonych przez niego molestowanych braci oraz innych jego ofiar. Przekaz w tej części koncentruje się na perfidii sprawców, psychologii pokrzywdzonego dziecka i trudnościach dowodowych w sprawie. W tym zakresie film jest niewątpliwie potrzebny. Trauma osób pokrzywdzonych pedofilią jest rzeczywiście trudna do wyobrażenia. Dużą trudność sprawiają im również dotyczące tego zeznania czy choćby proste mówienie o tym. Bracia Sekielscy, stając za takimi ofiarami, stosują jednak kompletnie nieetyczne metody dziennikarskie.

Oczywiste jest po pierwsze - $\mathrm{i}$ jest to prawda powtarzana zarówno w środowisku dziennikarskim, jak i prawniczym - że nagrywanie osób, których życie dobiega kresu, przez ich ofiary, a następnie publikowanie tego w formie filmu nie jest szczytem osiągnięć dziennikarstwa śledczego. Należy bowiem zapytać o cel takiego postępowania. Czy chodzi o pokazanie ich bezradności i niemożliwości odpokutowania zbrodni? A może o pokazanie, że każdy winny się tłumaczy? Jednak taka praktyka dziennikarska niestety jest także szkodliwa dla ofiar. Jest tak dlatego, że - jak wynika nie tylko z podobnych filmów, ale i z doświadczenia życiowego - im najbardziej zależy na spojrzeniu w oczy sprawcy, jego przyznaniu się i słowach przeprosin. Nie chodzi zwykle o pieniądze, procesy czy karę. Można się obawiać, że teraz żaden pedofil w Polsce - czy to w sutannie czy nie - nie przyzna się ofierze w konfrontacji face to face i nie przeprosi, bo będzie się bał bycia bohaterem kolejnego filmu. Etyka dziennikarska nakazywała wziąć ten efekt pod uwagę, zwłaszcza że nie był on trudny do przewidzenia. Już drugi film Braci Sekielskich pokazuje, jakie zebrali oni żniwo pierwszej z omawianych produkcji i jak zachowują się sprawcy.

Film „Zabawa w Chowanego”, podobnie jak jego poprzednik, stanowi naruszenie prawa i to w sposób oczywisty dla każdego, w tym dla każdego dziennikarza. Podaje się chociażby pełne dane osobowe księży, którzy nie wyrazili na to zgody. Podaje się pełne dane osób podejrzanych

[dostęp: 1.06.2020]. Publikacja ta nie zawiera jeszcze nazwiska biskupa stwierdzając, że po 16 maja 2020 r. będzie on powszechnie znany. Analiza aktywności medialnej prowadzi zresztą do wniosku, że film był wcześniej znany sporemu kręgowi osób, co pozwoliło im na staranne przygotowanie wypowiedzi, które następnie były prezentowane jako spontaniczne reakcje na film. 
bądź oskarżonych, choć zabrania tego wprost prawo prasowe ${ }^{26}$. Zgodnie $\mathrm{z}$ art. 13 ust. 1 i 2 pr.pras. „nie wolno wypowiadać $\mathrm{w}$ prasie opinii co do rozstrzygnięcia $\mathrm{W}$ postępowaniu sądowym przed wydaniem orzeczenia w I instancji”. Podobnie ,nie wolno publikować w prasie wizerunku i innych danych osobowych osób, przeciwko którym toczy się postępowanie przygotowawcze lub sądowe, jak również wizerunku i innych danych osobowych świadków, pokrzywdzonych i poszkodowanych, chyba że osoby te wyrażą na to zgodę". Zgodnie z prawem autorskim ${ }^{27}$ ochronie podlega wizerunek. Zgodnie z art. 81 p.a. jego rozpowszechnianie - co do zasady ${ }^{28}$ - wymaga „zezwolenia osoby na nim przedstawionej”. Ochronie podlega również imię i nazwisko ${ }^{29}$. Film ,Zabawa w chowanego” pozwala na przykład na bezproblemowe, precyzyjne ustalenie, gdzie mieszka ks. H. Film prezentuje cały jego wizerunek wraz z twarzą, chociaż Autorzy filmu mogli łatwo uniemożliwić jej identyfikację przez inny montaż. Tymczasem każdemu przysługuje prawo do sądu i prawo do obrony. Każdemu przysługuje też ochrona wizerunku, mieszkania i bezpieczeństwa osobistego. Ks. H. nie jest z tych gwarancji wyłączony. Z prawnego punktu widzenia nie ma przy tym znaczenia, że kłamie on wobec ofiar i ich rodziców oraz kluczy, chcąc uniknąć odpowiedzialności. Autorzy filmu nie mogą nie zdawać sobie sprawy, że publikacja tak zmontowanego filmu zagraża bezpieczeństwu osobistemu ks. H. Kreowanie takiej sytuacji nie jest uzasadnione

26 Ustawa z dnia 26 stycznia 1984 r. - Prawo prasowe, Dz. U. z 2018 r., poz. 1914; dalej: pr.pras.

27 Ustawa z dnia 4 lutego 1994 r. o prawie autorskim i prawach pokrewnych, Dz. U. z 2019 r., poz. 1231; dalej: p.a.

28 Na podstawie tego samego artykułu, ,zezwolenia nie wymaga rozpowszechnianie wizerunku: 1) osoby powszechnie znanej, jeżeli wizerunek wykonano w związku z pełnieniem przez nią funkcji publicznych, w szczególności politycznych, społecznych, zawodowych; 2) osoby stanowiącej jedynie szczegół całości takiej jak zgromadzenie, krajobraz, publiczna impreza". W braku wyraźnego zastrzeżenia zezwolenie nie jest wymagane, jeżeli osoba ta otrzymała umówioną zapłatę za pozowanie.

29 Zob. ustawę z dnia 10 maja 2018 r. o ochronie danych osobowych (Dz. U. z 2019 r., poz. 1781) oraz rozporządzenie Parlamentu Europejskiego i Rady (UE) 2016/679 z dnia 27 kwietnia 2016 r. w sprawie ochrony osób fizycznych w związku z przetwarzaniem danych osobowych i w sprawie swobodnego przepływu takich danych oraz uchylenia dyrektywy 95/46/WE (ogólne rozporządzenie o ochronie danych; Dz. Urz. UE L 119 z 4 maja 2016 r., s. 1-88). 
nawet jeśli popełnił on przestępstwo czy jest cynicznym kłamcą. Etyka dziennikarska również zabrania takich publikacji.

$\mathrm{W}$ tej sprawie pojawia się jednak także inny istotny wątek. Zarówno z wypowiedzi pokrzywdzonych, jak i z tego, co mówi ks. H. wynika, że on sam był ofiarą pedofilii. $\mathrm{Z}$ doświadczenia adwokackiego autor analizy wie, że wśród rzeczywistych sprawców pedofilii jest wielu takich, którzy sami byli molestowani w dzieciństwie. Zdarza się, że ofiara staje się sprawcą, bo nie przepracowała psychologicznie własnej traumy. Nie usprawiedliwia to oczywiście czynu sprawcy, który i tak powinien ponieść odpowiedzialność. Pokazuje to jednak, że chodzi o człowieka. Nie o potwora, którego należy zlinczować. W takich sytuacjach mamy oczywiście do czynienia z przestępcą, którego należy sprawiedliwie ukarać. To jest jednak rolą sądu.

Sam film jest zmontowany w sposób, który utrudnia zorientowanie się w chronologii przedstawianych zdarzeń. Ma to wytworzyć wrażenie, że kuria i zwłaszcza ks. bp Edward Janiak wiedział o czynach ks. H. od wielu lat i niczego z tym nie zrobił. Mówi się, że ks. H. był wielokrotnie przenoszony i że były to decyzje biskupa. Nie podaje się jednak w tym miejscu informacji o osobie sprawującej wówczas ten urząd. Pojawia się natomiast zdjęcie z jakiejś uroczystości z udziałem bpa Janiaka oraz formułowany jest zarzut, że coś wiedział, ale niczego nie zrobił ${ }^{30}$. Dalej, znowu nie wchodząc w chronologię, czytelnie sugeruje się, że winny jest bp Janiak, choć jednocześnie prezentowany prawnik chowa się za słowami „W mojej ocenie" ${ }^{31}$. Wszak ocena nie podlega weryfikacji w kategoriach prawda - fałsz.

Zniekształcana jest również rzeczywistość prawna. Pozory rzetelności ma stwarzać wyciąganie kodeksu z półki i cytowanie przepisu. Pomija się jednak rzeczywistą treść obowiązków wiążących przed 2019 r. Dalej w filmie prezentuje się najbardziej poruszające fragmenty wypowiedzi znajomej i prawników ofiar. Natomiast fakty są podane w sposób, który ma nie psuć prowadzonej narracji. Tak np. przekazano informację, że biskup w marcu 2016 r. odwołał ks. H. z funkcji proboszcza ${ }^{32}$. Sposób jej

\footnotetext{
30 38:11, 38:51, 39:42 filmu ,Zabawa w chowanego”.

31 45:43-46:05 omawianego filmu.

$3241: 57$ omawianego filmu.
} 
podania powoduje, że łatwo może ona umknąć oglądającemu. Podobnie jest z przypisywaniem bp. Janiakowi wiedzy o kłamstwach ks. H., który wprowadził w błąd rodziców ofiary podczas rozmowy w lutym 2016 r. $^{33}$ Atakuje się siostrę zakonną, która w oczywisty sposób nie miała w tej sprawie żadnej możliwości działania ${ }^{34}$. Film ma stworzyć wrażenie, że wszyscy obecną wiedzę posiadali wcześniej, a mimo tego nie reagowali. Jednak chronologiczne ułożenie przedstawianych zdarzeń posiadałoby zupełnie inną wymowę.

Powstaje pytanie o motyw przedstawionego postępowania. Wydaje się, że ks. bp Edward Janiak został wybrany na negatywnego bohatera filmu, ponieważ udało się uzyskać nagranie jego wypowiedzi z sądu, gdzie zeznawał jako świadek ${ }^{35}$, oraz nagranie jego rozmowy z rodzicami jednej z ofiar. Zdecydowała więc dostępność materiałów, a nie rzeczywiste okoliczności sprawy. W filmie nie wskazuje się rzeczywistych decydentów w sprawie ks. K., nie zwraca się uwagi na to, kto faktycznie przenosił ks. H. Pomija się fakt, że bp Janiak zdegradował ks. H. oraz zrealizował wszystkie obowiązki, jakie na nim spoczywały zgodnie z obowiązującym wówczas prawem. Już zresztą w poprzednim filmie Bracia Sekielscy mogli wskazać innych hierarchów podejmujących decyzje o przenosinach prezentowanych księży. Wydaje się więc, że rzeczywistość „nagięto” ze względu na istniejące nagrania, aby mogła powstać przemawiająca narracja prowadzona w filmie. Jednak uczciwa analiza dostępnych informacji (filmy, artykuły prasowe, strony internetowe diecezji i parafii, źródła prawa, w tym prawa kanonicznego) pozwalała na rzetelne przedstawienie faktów.

33 29:30-30:43, 31:05-31:53, 33:17-33:53, 35:50-36:10, 38:05-38:15 omawianego filmu.

34 33:54-35:30 omawianego filmu.

35 Fakt uzyskania tego nagrania budzi głęboki podziw autora opinii, bowiem jemu, jako adwokatowi, nigdy nie udało się uzyskać takiego nagrania wideo. Możliwe było wyłącznie otrzymanie nagrania audio, bo tylko to jest zgodne z prawem. Należy zwrócić uwagę, że rozpowszechnianie tego typu nagrań z pewnością będzie wpływać na swobodę wypowiedzi nagrywanych świadków w przyszłości. Z pewnością - ze szkodą dla wymiaru sprawiedliwości - będą oni brali po uwagę możliwość wycieku składanych zeznań i ich publikacji. 
3. MOŻLIWOŚCI OCHRONY PRAWNEJ KS. BPA EDWARDA JANIAKA ORAZ POZOSTAŁE NARUSZENIA PRAWA W FILMIE „ZABAWA W CHOWANEGO”

Koncentrując uwagę na możliwościach ochrony prawnej ks. bpa Edwarda Janiaka należy zauważyć, że - po pierwsze - może on dążyć do pociągnięcia do odpowiedzialności dyscyplinarnej i służbowej osób, które przekazały mediom nagranie z niejawnej rozprawy (,za zamkniętymi drzwiami" - art. 153 k.p.c. $)^{36}$. Jest to nagranie z kamery sądowej, będące materiałem, którego nie wydaje się stronom. Naruszono zatem prawo do wizerunku bpa Janiaka jako świadka, a ponadto jego wypowiedź pocięto.

Z kolei zawarte w filmie i odnoszące się do bpa Janiaka wypowiedzi prawników - jeśli są to adwokaci bądź radcowie prawni - mogą skutkować ich odpowiedzialnością dyscyplinarną. Hierarcha byłby w takim postępowaniu pokrzywdzonym. Profesjonalny prawnik wypowiadając się dla mediów musi zachować umiar i nie może wprzęgać zawodu zaufania publicznego w publicystykę, zwłaszcza po korzystnym dla swojego klienta zakończeniu sprawy sądowej. Nie może w szczególności w materiale prasowym atakować drugiej strony (choćby piastuna organu osoby prawnej). Oczywiście, jego publiczne wypowiedzi dotyczące prowadzonych spraw są często konieczne, ale nie mogą przekraczać granic wyznaczanych potrzebą obrony interesów klienta.

Omawiany materiał narusza dobra osobiste ks. bpa Edwarda Janiaka. Przez dobra osobiste - w myśl koncepcji obiektywnej A. Szpunara i Z. Radwańskiego - należy rozumieć ,uznane przez system prawny wartości (...), obejmujące fizyczną i psychiczną integralność człowieka, jego indywidualność oraz godność i pozycję w społeczeństwie, co stanowi przesłankę samorealizacji osoby ludzkiej"37. Co prawda, jak słusznie już w 1972 r. twierdził w komentarzu do Kodeksu cywilnego sędzia Sądu

36 Zgodnie z art. 153 ustawy z dnia 17 listopada 1964 r. - Kodeks postępowania cywilnego (Dz. U. z 2020 r., poz. 1575) „Sąd z urzędu zarządza odbycie całego posiedzenia lub jego części przy drzwiach zamkniętych, jeżeli publiczne rozpoznanie sprawy zagraża porządkowi publicznemu lub moralności lub jeżeli mogą być ujawnione okoliczności objęte ochroną informacji niejawnych” (§ 1). Może natomiast ,zarządzić odbycie posiedzenia lub jego części przy drzwiach zamkniętych na wniosek strony, jeżeli podane przez nią przyczyny uzna za uzasadnione lub jeżeli roztrząsane być mają szczegóły życia rodzinnego" (§ 2).

37 Radwański 2005, 161. Szerzej: Sadomski 2003, 15. 
Najwyższego H. Dąbrowski, „wydaje się też, że zupełnie ścisła i równocześnie wyczerpująca definicja [dóbr osobistych - przyp. M.S.] byłaby niemożliwa"38. Jednak w spornych przypadkach w praktyce stosuje się ujęcie zaproponowane przez A. Ciska, który określa dobra osobiste jako „wartości o charakterze niemajątkowym, ściśle związane z osobą ludzką, decydujące o jej bycie, pozycji w społeczeństwie, a będące wyrazem jej odrębności psychicznej i fizycznej oraz możliwości twórczych, uznane powszechnie w społeczeństwie i akceptowane przez dany system prawny"39.

Tym samym, w przypadku dóbr osobistych, kluczowe znaczenie ma ich indywidualny charakter. Nie są one jednak pozbawione elementu obiektywnego. Nie jest więc tak, że wyłącznie subiektywne przekonanie osoby decyduje o naruszeniu dóbr osobistych. Należy raczej przyjąć, że aby można było zasadnie mówić o naruszeniu dobra osobistego, musi być ono dobrem indywidualnym, a naruszenie musi być obiektywnie sprawdzalne. W przypadku wypowiedzi obiektywizm musi polegać na wskazaniu jej odniesienia do indywidualnej osoby. Zarzuty stawiane w filmie bez wątpienia mogą być odniesione do indywidualnego dobra osobistego w postaci dobrego imienia i czci.

Regulacje zawarte w art. 23 i 24 k.c. cechuje wysoki stopień ogólności. Określenie szczegółowych przesłanek odpowiedzialności było w tej sytuacji zadaniem doktryny i orzecznictwa ${ }^{40}$. W konsekwencji dobra osobiste postrzega się dziś przez pryzmat koncepcji praw podmiotowych, które mają charakter bezwzględny (są skuteczne erga omnes), są niezbywalne, ściśle związane z podmiotem i wygasają wraz ze śmiercią osoby fizycznej lub likwidacją osoby prawnej. Z praw podmiotowych mogą wynikać roszczenia niemajątkowe, które nie ulegają przedawnieniu. $\mathrm{Z}$ przepisu art. 24 k.c. wynika domniemanie bezprawności naruszenia dóbr osobistych, co w ewidentny sposób jest korzystne dla pokrzywdzonego, ponieważ dowód dotyczący działania w ramach prawa musi przedstawić pozwany (tzw. odwrócony ciężar dowodu). Ponadto przyjmuje się, że odpowiedzialność za naruszenie dóbr osobistych jest uniezależniona od winy

38 Resich 1972, 90.

39 Gniewek 2004, 87.

40 Resich 1972, s. 94 i powołane tam orzecznictwo i literatura; Winiarz 1980, 42 i powołane tam orzeczenie Sądu Najwyższego z dnia 6 grudnia 1967 r. (sygn. akt II CR 318/67). 
i następuje jedynie w oparciu o kryterium obiektywnej bezprawności naruszenia. Do okoliczności wyłączających bezprawność naruszenia dóbr osobistych należy zaliczyć: działanie w granicach porządku prawnego, wykonywanie prawa podmiotowego, ochronę interesu społecznego, jak również zezwolenie uprawnionego i sprzeczność żądania ochrony z zasadami współżycia społecznego ${ }^{41}$.

W zakresie dobra osobistego w postaci czci wytworzyła się wyjątkowa okoliczność uchylająca bezprawność, tj. prawo do krytyki ${ }^{42}$. W jego ramach dopuszczalne są bardziej zdecydowane wypowiedzi zwłaszcza na tematy dyskutowane w aktualnej debacie publicznej. Co więcej, oceny w ramach prawa do krytyki mogą być ostre, z uwagi na przedmiot tej krytyki czy ważkość tematu. Ostra krytyka może być bez wątpienia motywowana dążeniem do skutecznej ochrony dzieci przed pedofilią. Jej przedmiotem może być w szczególności „zamiatanie takich spraw pod dywan” przez hierarchię kościelną. Jednak również w tym przypadku niedopuszczalne jest posługiwanie się kłamstwem i manipulowanie faktami.

System ochrony dóbr osobistych stanowi realizację dwóch zasad prawa cywilnego: ochrony osoby ludzkiej oraz odpowiedzialności za szkodę ${ }^{43}$. W odróżnieniu od prawa karnego, prawo cywilne skupia się generalnie na funkcji kompensacyjnej za naruszenie określonych wartości. Najczęściej polega ona na zadośćuczynieniu pieniężnym bądź odszkodowaniu. Inny jest też stopień naruszeń chronionych praw; ,generalna różnica między zasadami ochrony prawa cywilnego i karnego będzie leżała w «ciężarze naruszenia», od którego począwszy będzie można domagać się ochrony w ramach danej gałęzi prawa"44.

W kwestii odpowiedzialności dziennikarza, odpowiedzialność cywilna ma tę pozytywną w porównaniu do karnej cechę, że zdecydowanie trudnej postawić zarzut ograniczania wolności słowa i prasy ${ }^{45}$. Możliwe jest jednak także poszukiwanie ochrony prawnokarnej. Dziennikarz podlega

41 Zob. Chaciński 2004, 117.

42 Zob. Resich 1972, s. 94 i powołane tam orzecznictwo i literatura; Winiarz, 1980, 41; wyrok Sądu Najwyższego z dnia 19 września 1968 r. (sygn. akt II CR 291/68), OSNCP 1969, poz. 200.

43 Szerzej: Wolter, Ignatowicz, Stefaniuk 2005, 16-19.

44 Kordasiewicz 1983, 150.

45 Skwarzyński 2009, 59-70. 
takiej samej odpowiedzialności karnej za swoje czyny jak każdy człowiek, jednak dużo kontrowersji budzi fakt odpowiedzialności karnej, będącej następstwem działań związanych $\mathrm{z}$ wykonywaniem zawodu dziennikarza. Chodzi zwłaszcza o takie przestępstwa, których można się dopuścić w związku z powstaniem i publikacją materiału prasowego ${ }^{46}$. Kwestia odpowiedzialności karnej dziennikarza stała się przedmiotem rozstrzygnięcia Trybunału Konstytucyjnego ${ }^{47}$ oraz jest problemem pojawiającym się przed Europejskim Trybunałem Praw Człowieka ${ }^{48}$.

W ostatnim czasie pojawiła się propozycja likwidacji art. 212 k.k., przynajmniej w części zakazującej naruszania czci przez dziennikarzy. Podkreślić trzeba jednak, że wśród norm karnych chroniących cześć, przestępstwo zniesławienia ma kluczową pozycję. Ono bowiem jest najczęstszą represją za naruszenie czci spotykającą nierzetelnego dziennikarza. W takiej sytuacji zasadne staje się pytanie, czy wyłączenie odpowiedzialności karnej dziennikarza nie doprowadziłoby do nadmiernego osłabienia ochrony czci.

Problematyczność odpowiedzialności karnej żurnalisty ma swoje źródło w konstytucyjnych gwarancjach wolności słowa. W ramach pracy zawodowej dziennikarza może dojść do konfliktu tej wolności z gwarantowanym każdemu prawem do ochrony czci i dobrego imienia (art. 47 Konstytucji RP z 2 kwietnia $1997 \mathrm{r}^{49}$ ). Powstaje wówczas problem, któremu z praw dać pierwszeństwo. Ustawa zasadnicza wprost tej kwestii nie rozwiązuje.

Prawo karne subsydiarnie wspomaga jednostkę w ochronie jej konstytucyjnego prawa do dobrego imienia. Dobrem chronionym przez normę odnoszącą się do zniesławienia jest cześć człowieka, co stanowi wyraz

46 Są nimi m.in. zniesławienie (polegające na umyślnym pomawianiu osoby, grupy osób, instytucji, osoby prawnej lub jednostki organizacyjnej nieposiadającej osobowości prawnej o takie postępowanie lub właściwości, które mogą poniżyć ją w opinii publicznej lub narazić na utratę zaufania; art. 212 k.k.) i zniewaga (czyli naruszenie czci wewnętrznej osoby choćby pod jej nieobecność lecz publicznie lub w zamiarze, aby zniewaga do tej osoby dotarła; art. 216 k.k.). Oczywistym jest przy tym, iż odpowiedzialność karna żurnalisty za zniesławienie i zniewagę może być egzekwowana tylko z przepisu określającego typ kwalifikowany przestępstwa (odpowiednio art. $212 \S 2$ i art. $216 \S 2$ k.k.).

47 Wyrok TK z dnia 30 października 2006 r. (sygn. akt P 10/06), OTK-A 2006, nr 9, poz. 128 .

48 Szerzej: Stefanicki 2004, 3-25.

49 Dz. U. z 1997 r. Nr 78, poz. 483 z późn. zm. 
pomocy państwa $\mathrm{w}$ ochronie tej wartości konstytucyjnej. W przypadku omawianego przestępstwa chodzi o cześć zewnętrzną, czyli poważanie jednostki przez innych ludzi, jej pozycję społeczną i zaufanie, którym się cieszy. Rozumie się ją jako honor, dobre imię, godność osobistą ${ }^{50}$. Zgodnie z art. 212 k.k. w przypadku każdego obowiązuje domniemanie, że ,jest uczciwy, nie zhańbiony poniżającymi uczynkami i wolny od zasługujących na potępienie przymiotów" ${ }^{51}$. Domniemanie takie przysługuje także osobie skazanej lub prowadzącej działalność społecznie nieakceptowalną ${ }^{52}$.

Z drugiej strony, wartościami konstytucyjnymi są także: wolność prasy i środków społecznego przekazu (art. 14 Konstytucji RP) oraz wolność wyrażania swoich poglądów, rozpowszechniania i pozyskiwania informacji, a także zakaz cenzury prewencyjnej (art. 54 Konstytucji RP). Oba powołane przepisy pozwalają określić sferę uprawnień składającą się na wolność słowa. Jest ona fundamentem demokratycznego państwa prawnego, dlatego sposób jej realizacji, poprzez wolność prasy i druku, został określony w pierwszym rozdziale polskiej ustawy zasadniczej. Podkreślono w ten sposób funkcję wolności słowa jako elementarnej gwarancji demokracji ${ }^{53}$.

Należy stwierdzić, iż na gruncie konstytucyjnym i aksjologicznym wolność wypowiedzi jest dobrem, które w konflikcie z ochroną honoru osoby musi ulec ograniczeniu. Przemawia za tym szereg argumentów. Rolą prasy, zgodnie z art. 1 pr.pras., jest urzeczywistnianie prawa obywateli do ich rzetelnego informowania i kontrola życia publicznego. Już sama konstrukcja przepisu kreuje „podporządkowanie” prasy prawu do informacji. Należy też zwrócić uwagę na art. 233 Konstytucji RP, w którym zabrania się ograniczenia wolności i praw wynikających z art. 30 oraz art. 47 (i szeregu innych przepisów) ustawy zasadniczej nawet w czasie stanu wojennego i wyjątkowego. Jak celnie stwierdził Trybunał Konstytucyjny, „W świetle art. 31 ust. 3 Konstytucji nie ma podstaw, by wolności słowa przypisać domniemanie pierwszeństwa ochrony przed innymi konstytucyjnymi wolnościami i prawami. Domniemanie tego rodzaju można oprzeć na szczególnym znaczeniu, jakie ustawodawca konstytucyjny przy-

50 Wąsek 2004, 1080.

51 Kulesza 1984, 34-35.

52 Zob. tamże, 35; Wąsek 2004, 1080; Buchała 1999, 642.

53 Garlicki 2004, 114. 
wiązuje do konkretnej wolności lub prawa. W tym zakresie zwrócić należy uwagę, że dobra, o których mowa w art. 47 Konstytucji, są chronione przez tzw. prawa niederogowalne, tj. takie, których nie można ograniczyć nawet w stanie wojennym i stanie wyjątkowym" ${ }^{54}$. W art. 233 Konstytucji RP nie uwzględniono natomiast zakazu ograniczenia prawa do informacji i swobody wyrażania poglądów, gwarantowanego w art. 54 ustawy zasadniczej, w którym określa się również zakaz cenzury prewencyjnej. Jak zauważa A. Zoll, zakaz ten ,nie oznacza zniesienia ochrony czci. Wręcz przeciwnie zakaz cenzury prewencyjnej zwiększa odpowiedzialność osób dopuszczających się krytyki za pomocą środków masowego komunikowania. Daje temu wyraz art. $212 \S 2$ "55. Są to czytelne znaki, dobra osobiste są dla prawodawcy kategorią podlegającą szczególnej ochronie. Ochrona ta jest na tyle szeroka, że zapewnia ochronę dóbr osobistych nawet w sytuacjach ekstremalnych. Skoro sytuacja zagrożenia państwa nie może być powodem ograniczenia odnoszących się do tych dóbr praw, to tym bardziej nie może nim być zagrożenie, zwłaszcza znikome, wolności słowa. Oczywiście, nie oznacza to bezwzględnego prymatu dóbr osobistych nad wolnością słowa. Z takim prymatem mamy do czynienia wtedy, gdy wolność słowa pozostaje jedyną wartością, którą zasłania się dziennikarz naruszający dobra osobiste i brak jest społecznie uzasadnionego interesu, którego jego wypowiedź miałaby bronić.

Wolność słowa nie jest celem samym w sobie. Jest środkiem służącym swobodzie debaty publicznej, przepływu informacji i wymiany poglądów. Jeżeli ten środek wykorzystamy w sposób naruszający czyjąś godność osobistą, nie mogąc uzasadnić tego pogwałcenia jakimś innym bronionym przez nas dobrem, zrozumiałym jest, że poniesiemy odpowiedzialność. Nawet publikacja przez dziennikarza rzetelnego i prawdziwego materiału prasowego zgodnie z zasadami etyki zawodowej wymaga uzasadnionej przyczyny. Dlatego słuszny jest pogląd E. Łętowskiej, że ,zarzut prawdziwy uczyniony publicznie - lecz za pośrednictwem środków masowego komunikowania się - z reguły uznawać należy za czyniony w obronie społecznie

54 Uzasadnienie wyroku TK z dnia 30 października 2006 r. (sygn. akt P 10/06), pkt 4.3.

55 Buchała 1999, 652. 
uzasadnionego interesu"56. Jak jednak wynika z cytowanego wyżej uzasadnienia wyroku Trybunału Konstytucyjnego z dnia 30 października 2006 r. (P 10/06) zdarzyć się może sytuacja odmienna, kiedy takiego interesu nie ma. Jako przykład można wskazać przypadek podany przez Radę Etyki Mediów, w którym „Tygodnik Płocki” (a ściślej pracujący w nim dziennikarze) atakował na swoich łamach miejscowy urząd skarbowy z powodu własnych problemów $\mathrm{z}$ fiskusem ${ }^{57}$, a więc dla interesów ewidentnie partykularnych. Tę kwestię zauważył także W. Wolter: „Musi to być jednak krytyka rzeczowa, nie dyktowana względami osobistej animozji, (...) i nie może zmierzać jedynie do zniszczenia przeciwnika"58. Dlatego żurnalista wykorzystujący swoją funkcję społeczną do świadomego uderzania w cześć innej osoby poniesie konsekwencje swojego czynu, ponieważ „sam fakt prawdziwości zarzutu stawianego publicznie nie może jeszcze przemawiać za społeczną opłacalnością poświęcenia czci drugiej osoby. (...) [Musi on - przyp. M.S.] obiektywnie służyć obronie społecznie uzasadnionego interesu" 59 .

Szczególna ochrona czci znajduje wyraz w konstrukcji art. 213 k.k. ${ }^{60}$ Istotą przestępstwa zniesławienia jest postawienie zarzutu. Jego cechy zdefiniowane zostały w znamionach określonych w art. $212 \S 1$ k.k., a dodatkowe znamię - w postaci nieprawdziwości - w art. $213 \S 1-2$ k.k. Treścią zarzutu jest pomówienie pokrzywdzonego o takie postępowanie lub właściwości, które mogą poniżyć go w opinii publicznej lub narazić na utratę zaufania potrzebnego dla danego zawodu lub rodzaju działalności. Natomiast czyn polegający na pomawianiu, zgodnie z definicją słownikową, oznacza zarzucanie czegoś komuś, posądzanie, oskarżanie o coś, niesłusznie przypisanie czegoś komuś ${ }^{61}$. Można tego dokonać także za pomocą

56 Zdanie odrębne sędzi TK Ewy Łętowskiej do wyroku z dnia 30 października $2006 \mathrm{r}$. (sygn. akt P 10/06), pkt 2.

57 Największe grzechy polskich mediów wedtug Rady Etyki Mediów, https://notatek. $\mathrm{pl} /$ radia-i-tv-najwieksze-grzechy-polskich-mediow-wed-ug-rady-etyki-mediow [dostęp: 1.06.2020].

58 Andrejew, Świda, Wolter 1973, 525.

59 Buchała 1999, 656-657.

${ }^{60}$ Zob. wyrok TK z dnia 12 maja 2008 r. (sygn. akt SK 43/05), OTK-A 2008, nr 4 , poz. 57; Skwarzyński 2008, 198-208.

61 Szymczak 1989, 797. 
gestu czy w formie pytania. Pomówieniem będzie postawienie zarzutu we własnym imieniu, ale również - co do zasady - jego powtarzanie. Istotne jest przy tym, w jakim celu powtarza się ów zarzut. Nie popełnia bowiem przestępstwa ten, kto czyni tak tylko po to, by z zarzutem polemizować lub go obalić6 ${ }^{6}$.

Pojawia się oczywiście pytanie, czy odpowiedzialność za zniesławienie powinna przybierać formę tak represyjną, jak sankcja karna. Odpowiedź na nie jest jednak twierdząca, ponieważ chodzi o ochronę szczególnie ważnego dobra, jakim jest godność osobista. Przedmiotem ochrony prawa karnego są generalnie dobra mające dużą wartość z punktu widzenia systemu prawnego konkretnego państwa. Ochrona czci przez normy karne stawia to dobro wśród dóbr szczególnie chronionych przez państwo. Ochrona karna jest adekwatna do znaczenia chronionej wartości, bowiem godność osobista - obok zdrowia i życia - jest bezpośrednią emanacją godności człowieka. Jak stwierdził Trybunał Konstytucyjny, „W treści każdego prawa i wolności należy poszukiwać pewnego rdzenia treściowego, którego naruszenie jest wykluczone z uwagi na to, że stanowi on conditio sine qua non zasady godności (...). W tych warunkach należy uznać, że im silniejszy jest związek danego prawa albo wolności z istotą godności człowieka, tym lepiej (skuteczniej) winno być ono chronione przez władze publiczne"63. Andrzej Zoll w wypowiedzi dla dziennika „Rzeczpospolita” podkreślił, że zgadza się z orzeczeniem Trybunału w sprawie konstytucyjności art. 212 k.k.: „muszę powiedzieć, że nie przystąpiłem do skargi konstytucyjnej dotyczącej art. 212 jeszcze jako RPO. Te przepisy, dobrze stosowane, są absolutnie zgodne z konstytucyjną ochroną czci. Nie możemy zapominać, że oprócz wolności słowa jest jeszcze ochrona czci w konstytucji i to musi być wyważone". Profesor podał także kilka innych argumentów przemawiających za tym stanowiskiem. Wskazał, że chodzi o ,problem godności człowieka i ta ochrona karna ma pewien charakter symboliczny. Wskazuje na wartość czci, godności, dobrego imienia”. Przypomniał również o zjeździe przedstawicieli katedr prawa karnego w Gnieźnie, podczas którego „wszyscy karniści polscy, którzy byli na tej konferencji, zdecydowanie opowiada-

62 Wąsek 2004, 1081.

63 Uzasadnienie wyroku TK z dnia 30 października 2006 r. (sygn. akt P 10/06), pkt 4.3. 
li się za tym, by utrzymać prawną ochronę czci" ${ }^{64}$. Ścisły związek czci z godnością człowieka jest więc niewątpliwy, dlatego stosowanie kary kryminalnej jest proporcjonalne do chronionego dobra i znaczenia ewentualnych na nie zamachów.

Podnoszony jest jednak argument, że kryminalizacja zachowań wypełniających znamiona czynów zabronionych, lecz dokonanych w ramach wypełniania zawodu dziennikarza może spowodować ograniczenie wolności słowa i wywołać w odniesieniu do swobody debaty publicznej „efekt mrożący" ${ }^{65}$. Pogląd ten jest jednak wysoce dyskusyjny. Zauważyć bowiem należy, iż mimo ważnej roli społecznej, jaką jest informowanie społeczeństwa, ustawodawca nie zdecydował się na uwzględnienie w jakimkolwiek akcie normatywnym immunitetu materialnego wyłączającego odpowiedzialność karną. Co więcej, odpowiedzialność karna subsydiarnie powinna być stosowana wyłącznie w skrajnych przypadkach.

Co do pozostałych kwestii wynikających z upublicznienia filmu „Zabawa w chowanego", organy dyscyplinarne winny zbadać, czy źródłem wycieku nagrania z rozprawy nie jest prawnik profesjonalny oraz czy prawidłową praktyką jest udzielanie porad prawnych pokrzywdzonym przy kamerze i dziennikarzach ${ }^{66}$. Natomiast prokuratura winna się zająć kwestią wycieku nagrania sądowego z rozprawy za zamkniętymi drzwiami (niejawnej), a wraz z Urzędem Ochrony Danych Osobowych - także zagadnieniem legalności publikowania tych danych. Sprawa ta nie powinna zostać zignorowana także przez samorząd dziennikarski. W oczywisty sposób ujawnia się też rola, jaką ma w tych sprawach do odegrania Rzecznik Praw Obywatelskich.

64 D. Gajos, Dziennikarze moga być karani za pomówienie, www.rzeczpospolita. pl 2006 [dostęp: 1.06.2006].

65 Zdanie odrębne sędziego TK Marka Safjana do wyroku z dnia 30 października 2006 r. (sygn. akt P 10/06), pkt 5.

66 12:42-12:49 filmu „Zabawa w chowanego”. Prawnik spisuje tu dane dotyczące sprawy i sprawcy oraz sporządza wstępne notatki przy kamerach i dziennikarzach. Taka praktyka powinna spotkać się ze zdecydowaną reakcją samorządu. Zaufanie między klientem a profesjonalnym prawnikiem i tajemnica adwokacka/radcowska powinny pozostać wartościami objętymi zdecydowaną ochroną. 


\section{POZAPRAWNE ASPEKTY PODJĘCIA AKTYWNEJ OBRONY}

Można sądzić, że wybór biskupa kaliskiego na symbol hierarchicznej patologii w zwalczaniu pedofilii w Kościele Katolickim wynikał także z tego, że nie jest to diecezja mająca zbyt wielkie możliwości, która nie dysponuje stałą pomocą renomowanych kancelarii prawnych. Opisany wyżej warsztat i poziom dziennikarstwa spotkałby się bez wątpienia z negatywną oceną sądów. Zatem wybór bpa Janiaka nie był przypadkowy. Wydaje się bowiem, że Autorzy filmu liczą na wytoczenie im procesu, przez który chcą dodatkowo rozprzestrzenić swój przekaz i zbudować grunt pod planowany atak na Jana Pawła II, przy okazji uruchamiając zapewne zbiórkę pieniędzy na pomoc prawną przeciwko biskupowi. Plan nie jest trudny do przejrzenia. Jego realizacja zgodnie z przyjmowanymi założeniami wymagała jednak wyboru takiego hierarchy, którego będzie można zmarginalizować i któremu nie będzie łatwo o zapewnienie sobie profesjonalnej obrony.

Zdaniem autora analizy, chociaż ks. bp Edward Janiak ma w omawianej sprawie rację i prawo po swojej stronie, to jednak z wyżej wskazanych powodów nie powinien występować z pozwem lub zawiadomieniem o popelnieniu przestępstwa, czy też z prywatnym aktem oskarżenia. Powinien raczej skoncentrować się na rzetelnym przedstawieniu stanu faktycznego sprawy, koncentrując się na okresie, w którym to on odpowiadał za Diecezję Kaliską (wskazując m.in., że po marcu 2016 r. ks. H. był faktycznie odsunięty od pracy z dziećmi). Należałoby opublikować chronologię zdarzeń. Ponadto autor analizy uważa, że konieczne jest opublikowanie informacji, czy w czasie, kiedy bp Janiak był biskupem kaliskim, ks. H. nie sprawiał problemów (czy wszystkie jego przestępstwa były popełnione przed 2012 r., a po tym roku nie było na niego skarg?). Wyjaśnić należy wreszcie, jak ks. H. był odbierany przez wiernych w Chwaliszewie i szpitalu, w którym posługiwał.

\section{PODSUMOWANIE}

Przeprowadzone rozważania prowadzą do wniosku, że ks. bp Edward Janiak nie naruszył żadnych obowiązków obciążających go zgodnie z prawem polskim czy prawem kanonicznym w związku z czynami ks. H. i ks. K. Do takiego wniosku prowadzi uwzględnienie dat wejścia w życie 
przepisów ustanawiających odnoszące się do tego obowiązki (a więc przede wszystkim obowiązek denuncjacji pedofilii oraz obowiązek zgłoszenia tego rodzaju przypadków Stolicy Apostolskiej) oraz dat objęcia przez niego istotnych w sprawie urzędów. W omawianym filmie zafałszowano jednak zarówno chronologię zdarzeń, jak i rzeczywistość prawną. Natomiast wybór bpa Janiaka na negatywnego bohatera „Zabawy w chowanego” wynikał - jak można sądzić - nie tyle z racji merytorycznych, ile raczej z faktu dysponowania nagraniami jego wypowiedzi, które można było w filmie wykorzystać. Najważniejszym instrumentem obrony hierarchy powinno być $\mathrm{w}$ tej sytuacji propagowanie prawdziwych informacji zarówno na temat obciążających go obowiązków, jak i podjętych przez niego działań.

\section{BIBLIOGRAFIA}

Andrejew, Igor, Witold Świda, Władysław Wolter. 1973. Kodeks Karny z komentarzem. Warszawa: Wydawnictwo Prawnicze.

Balcerzak, Michał. 2008. „Prawo do obrony a ochrona małoletnich pokrzywdzonych przed wtórną wiktymizacją. Glosa do wyroku ETPC z dnia 19 czerwca 2007 r., 21508/02". Gdańskie Studia Prawnicze - Przegląd Orzecznictwa 1: 175-182. Banaś-Grabek, Marta, Bartłomiej Gadecki, Joanna Karnat, Aneta Łyżwa, Rafał Łyżwa. 2020. Kodeks karny. Czesść szczególna. Art. 148-251. Komentarz. Warszawa: Legalis.

Bojarski, Tadeusz. 2016. Kodeks karny. Komentarz. Warszawa: LEX.

Buchała, Kazimierz. 1999. Kodeks karny, część szczególna. Komentarz tom II. Kraków: Zakamycze.

Chaciński, Jacek. 2004. Prawa podmiotowe a ochrona dóbr osobistych. Lublin: Wydawnictwo KUL.

Dohnalik, Jan. 2015. „Prawo kanoniczne wobec nadużyć seksualnych duchownych względem dzieci i młodzieży". Dziecko krzywdzone. Teoria, badania, praktyka 1(14): 50-66.

Domaszk, Arkadiusz. 2012. „Reakcja Kościoła na nadużycia seksualne wobec nieletnich ze strony duchownych”. Seminare. Poszukiwania Naukowe 31: 69-86. Gardocki, Lech. 2020. Przestępstwa przeciwko państwu i dobrom zbiorowym. System prawa karnego, tom 8 . Warszawa: Legalis.

Garlicki, Leszek. 2004. Polskie prawo konstytucyjne. Zarys wyktadu. Warszawa: Liber. 
Garlicki, Leszek. 2010. „Komentarz do art. 9 Konwencji”. W: Konwencja o ochronie praw człowieka i podstawowych wolności. Tom I. Komentarz do artykutów 1-18, red. Leszek Garlicki, 550-582. Warszawa: C.H. Beck.

Gniewek, Edward. 2004. Kodeks cywilny. Komentarz, tom I. Warszawa: C.H. Beck.

Kierski, Michał. 2018. „Jednokrotne przesłuchanie pokrzywdzonego w trybie art. 185a k.p.k. - zasada czy wyjątek?" Prokuratura i Prawo 11: 87-97.

Konarska-Wrzosek, Violetta. 2018. Kodeks karny. Komentarz. Warszawa: LEX.

Kordasiewicz, Bogudar. 1983. „Ochrona czci w prawie karnym i prawie cywilnym”. Studia Prawnicze 2: 140-152.

Kulesza, Witold. 1984. Zniestawienie i zniewaga. Warszawa: Wydawnictwo Prawnicze. Mazowiecka, Lidia (red.). 2012. Wiktymizacja wtórna. Geneza, istota i rola $w$ przekształcaniu polityki traktowania ofiar przestęstw. Warszawa: Wolters Kluwer Polska.

Mazurkiewicz, Dariusz. 2018. „Prewencja nadużyć seksualnych wobec małoletnich w kanonicznym polskim prawodawstwie partykularnym". Studia Paradyskie 28: 45-68.

Orzeszyna, Krzysztof, Michał Skwarzyński, Robert Tabaszewski. 2020. Prawo międzynarodowe praw człowieka. Warszawa: C.H. Beck.

Radwański, Zbigniew. 2005. Prawo cywilne - część ogólna. Warszawa: C.H. Beck. Resich, Zbigniew (red.). 1972. Kodeks cywilny. Komentarz, tom I. Warszawa: Wydawnictwo Prawnicze.

Sadomski, Jacek. 2003. Naruszenie dóbr osobistych przez media. Warszawa: Instytut Wymiaru Sprawiedliwości.

Skwarzyński, Michał. 2008. „Charakter prawny art. 213 kodeksu karnego”. Prokuratura i Prawo 7-8: 198-208

Skwarzyński, Michał. 2009. „Odpowiedzialność dziennikarza za naruszenie dóbr osobistych”. W: Ogólnopolski Zjazd Cywilistów Studentów - 45 lat kodeksów cywilnych, red. Jan J. Skoczylas, 59-70. Lublin: Wydawnictwo KUL.

Skwarzyński, Michał. 2014. „Prawo człowieka do obrony a postępowanie wykroczeniowe w Polsce". W: Straż gminna jako organ kontroli ruchu drogowego, red. Artur Mezglewski, 103-121. Lublin: Wydawnictwo KUL.

Skwarzyński, Michał. 2018. „Ochrona przed nierównym traktowaniem spółek powołanych przez osoby prawne związków wyznaniowych w europejskim systemie praw człowieka”. Przegląd Sejmowy 2: 71-88.

Skwarzyński, Michał. 2019. „Spowiedź jako przedmiot ochrony prawa człowieka do wolności sumienia i religii spowiednika”. W: Prawo do prywatności $w$ Kościołach i innych związkach wyznaniowych. Od tajemnicy duszpasterskiej do ochrony danych osobowych, red. Tadeusz J. Zieliński, Michał Hucał, 223-238. Warszawa: Wydawnictwo ChAT. 
Stefanicki, Robert. 2004. „Kryterium konieczności wprowadzonych ograniczeń wolności wypowiedzi w świetle orzecznictwa Europejskiego Trybunału Praw Człowieka". Przegląd Sądowy 7-8: 3-25.

Stefański, Ryszard. 2020. Kodeks karny. Komentarz. Warszawa: Legalis.

Szymczak, Mieczysław. 1989. Stownik języka polskiego, tom II. Warszawa: Państwowe Wydawnictwo Naukowe.

Wąsek, Andrzej (red.). 2004. Kodeks karny. Część szczególna. Komentarz, t. I. Warszawa: C.H. Beck.

Winiarz, Jan (red.). 1980. Kodeks cywilny z komentarzem. Warszawa: Państwowe Wydawnictwo Naukowe.

Wolter, Aleksander, Jerzy Ignatowicz, Krzysztof Stefaniuk. 2001. Prawo cywilne. Zarys części ogólnej. Warszawa: LexisNexis.

Wójcik, Jerzy. 2014. Kryminologia. Współczesne aspekty. Warszawa: LEX.

Zoll, Andrzej. 2013. Kodeks karny. Część szczególna. Tom II. Komentarz. Warszawa: LEX.

\section{A LEGAL ANALYSIS OF THE CASE OF BISHOP EDWARD JANIAK IN THE CONTEXT OF THE MOVIE "HIDE AND SEEK" BY MAREK AND TOMASZ SEKIELSKI}

\section{Abstract}

The present paper focuses on several key issues relating to the case of Bishop Edward Janiak in the context of the movie by Marek and Tomasz Sekielski titled "Hide and seek". The point of departure is to define the duties of the bishop under Polish law and canon law after he was informed of cases of pedophilia involving his subordinate clergy. Then, the analysis proceeds to assess the factual reliability of the movie, to what extent it violates the current law, the question of the legal protection of Bishop Janiak as well as the extra-legal aspects of his active defense. The paper concludes that the movie under discussion misrepresents not only the chronology of the events, but also the legal situation. As far as depicting Bishop Janiak as the negative character of "Hide and seek" is concerned, it was not motivated by the objective reasons, but was caused by the simple fact that the authors had the bishop's recordings at their disposal and therefore used them in the movie.

Key words: combating pedophilia; Catholic Church; journalism; canon law 